AGRICULTURE AND BIOLOGY JOURNAL OF NORTH AMERICA

ISSN Print: 2151-7517, ISSN Online: 2151-7525, doi:10.5251/abjna.2011.2.7.1126.1134

(C) 2011, ScienceHuß, http://www.scihub.org/ABJNA

\title{
Evaluation of genetic diversity of an Algerian durum wheat (triticum durum desf.) collection.
}

\author{
Boudour L.*; Gharroucha H**; Boukaboub A; Bouchtab K;
}

Baka M; Samra K.

* Laboratoire de Genetique, Biochemie et Biotechnologie, Faculté des Sciences de la Nature et de la Vie, Constantine Mentouri University. ALGERIA.

** Laboratoire des Resources Génétiques et Amélioration des Plantes, Faculté des Sciences de la Nature et de la Vie, Constantine Mentouri University. ALGERIA.

\begin{abstract}
Durum wheat (Triticum durum Desf.) has been extensively cultivated in Algeria for many centuries. During this long period, the species encountered a large diversification implied by the great diversity of climates that led to great genetic diversity of the species. The purpose of this study is to improve the management of phytogenetic resources that can serve as potential breeders for the amelioration of wheat. The study aims at evaluating the diversity of 1019 accessions of durum wheat from different regions of Algeria and which are stored at the Constantine ITGC. The analysis of the results concerning phenological and morphophysiological characters revealed an important intra and intervarietal genetic variability. Subsequently it appeared that the 1019 accessions belong to 19 botanic varieties that differ mainly by the cob, silk and grain colours. Among the characters involved in this study, some appeared to have a direct connection with the adaptation to water stress and thus allowed us identifying the most resistant varieties.
\end{abstract}

Key words: Durum wheat, Trititicum durum, phytogenetic resources, Population,Classification, genetic diversity, morphological features, water stress.

\section{INTRODUCTION}

The range of genetic variability of the cultivated wheat varieties has considerably diminished in the last years. The swift and continual erosion of the "genetic legacy" of durum wheat resulted in:

- A reduction of the output improvement possibility.

- An increase of vulnerability to diseases and sensitivity to adverse climatic changes (Feldman and Sears, 1981; Asins and Carbonell, 1989).

The selection of new varieties of wheat, which was achieved to the detriment of species variability so that each of them represented a unique genotype, caused the local populations initially composed of several genotypes each to be replaced (Feldman and Sears1981).

The need to preserve phytogenetic resources is now a political and economic stake. Indeed, the reutilisation of these resources requires first an accumulation of data on the genetic bases of targeted agronomic characters. Therefore, both current and future agricultural production depends in large part on the available genetic diversity as reported by Cauderon, (1985).

Since the independence of Algeria in 1962, no selection or amelioration strategy was constantly followed. No studied collections were reported by the research studies performed to this day. The selection process of local cultivars encountered no regression since 1965. Even the introduction of new varieties between 1967and 1968 could not decelerate the loss of the local cultivars, (Abdelguerfi and Laouar, 1999).

The progressive disappearance of the traditional and spontaneous forms forced the scientists to realise the necessity to save and preserve the existing variability. During the last decades, some preservation and valorisation strategies of the genetic resources were undertaken throughout Algeria. Nowadays, it is ever urgent to reflect on a better strategy of preservation and valorisation of the phytogenetic resources. 
The purpose of this work is attempting to make a botanic classification of a collection of 1019 accessions of durum wheat (Triticum durum Desf) from different regions of Algeria based on a phenological and morphophysiological approach.

\section{MATERIAL AND METHODS.}

Vegetal Material: The study material is an Algerian hard wheat collection (Triticum durum Desf.) consisting of 1019 accessions which were harvested during the year 1988-89 in different regions of the country: In the East (Sétif, Batna, Constantine, Annaba, Guelma, Bordj-Bouariredj, Bousaada and Tebessa); in the West (Meliana, Mostaganem, Tiaret, Saïda, and Relizane); in the North (Medea) and in the South (Biskra and Tougourt oasis). This collection is currently kept at the Institut Technique des Grandes Cultures (ITGC) in Algeria and in the International Center of Agricultural Research in Arid Zone (ICARDA) in Syria.

Starting Experiment : The study was carried out at the experimental facility of the ITGC in El- Khroub (Constantine-Algeria), located at 640 metres high in the inner high plains which are characterised by a mean annual rainfall of $450 \mathrm{~mm}$.

Vegetal material is sowed as a tree nursery devised without repetitions (Fig. 1).

The arrangement consists of 10 basic lots of 99 rows of $1 \mathrm{~m}$ long with a $25-\mathrm{cm}$ space-line and $50 \mathrm{~cm}$ between lots.Each genotype is represented by 5 plants / row.

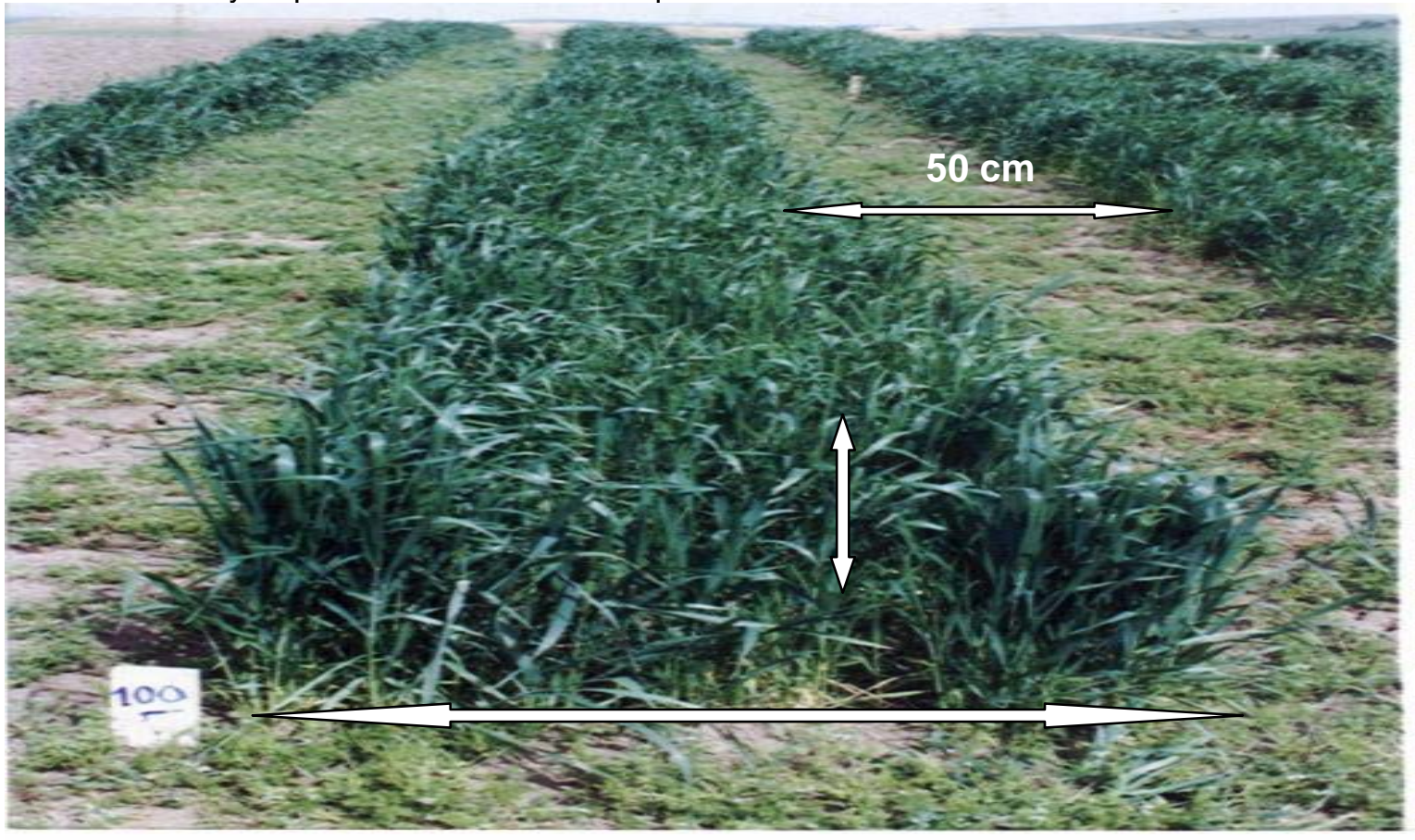

Fig 1: Experiment Device

The lots were surrounded by an edge of several barley-sowed rows. The performed experiment is resumed during four successive farming campaigns.

\section{Characteristics of the soil:}

The soil of the facility is naturally calcimagnesic of brown colour with a high water retention capacity as well as $\mathrm{PH}=7.85, \mathrm{CC}=30.3$, a wither point $(\mathrm{PtF})=$ 18.1 ; clay $=37.50 \% ;$ active limestone $=12.29$ $\%$ and organic matter $(\mathrm{MO})=0.85 \%$ ( Anonymous, 2001).

\section{Studied Parameters}

\section{Morphological Parameters}

In order to make the botanic classification of the different genotypes of the accession, we highlighted the morphological characters.

\section{Qualitative Characters}

The qualitative characters are measured with scale ranging from 1 to 5 or 1to 9, set by Feckes, ('1954) ; Laumont and Erroux, (1961); Asfis, (1990) and 
UPOV, (1990). These characters, relative to the morphology of the ear and concerning the master cord are:

- form ear (FE), compacity ear (COE) and ear color (EC).

- form awn (FA) and color awn (CA).

- form glume (FGL), color glume (CGL) and pilosity glume (PGL) .

- form beak (FBE) and length beak (LBE).

- length (LT) and form of truncation (FT).

- pilosity rachis (PR).

- color (CGR) and form of the grain (FGR ).

- glaucescence of standard leaf (GSL), sheath (GS), peduncle (GP) and ear (GE).

- form of the straw (FS)

Quantitative Characters: The quantitative parameters, also measured to better discriminate the different genotypes within the varieties, are:

- time length of vegetative phases counted in levy days

Until the ear emergence stage (DE).

- height of the stem in $\mathrm{cm}(\mathrm{HS})$.

- length of the neck in $\mathrm{cm}(\mathrm{LN})$.

- length of the ear in cm (LE).

- number of ears (NE).

- number of spikelets (NSP).

- length of awn in cm (LA).

- the surface of the standard leaf in $\mathrm{cm}^{2}(\mathrm{SL})$ is calculated by multiplying

- length by width by coefficient 0.749 (Spagnoletti Zeuli and Qualset, 1990).

- lumber of grains/ ear (NGR/E).

- weight of the grains/ear (WGR/E).

- weight of one thousand grains (WTG)
The 31 qualitative and quantitative parameters listed below are measured on 8 individuals according to genotype. They allowed us to sort, identify and classify the 1019 genotypes.

\section{RESULTS AND DISCUSSION}

Dichotomy Classification: Qualitative parameters related to the ear morphology at grain maturity showed a variability of the forms and colors of the ears, awns and grains. From these characters, we could identify 19 botanic varieties, each one of them consisting of a population of various genotypes (Tab.1) that are divided into 2 large groups:

- The group of varieties leucurum, affine, leucomelan, reichenbachi, hordeiforme, murciense, alexandrinum, erythromelan, algeriense, provinciale and obscurum, which are characterised by a hairless ear having extremely variable colors (white, red, black or blue), a awn (white, black or red) and by a white or red grain.

- The group of varieties valenciae, fastuosum, circumflescum, melanopus, africanum, italicum, aegytiacum and apulicum that include a pubescent ear with varied colors (white, red, black or blue), colored awn (white, red, black) and white or red grains.

However, for 1019 accessions from 19 varieties, it is noticed the clear absence of genotypes with pubescent black ears having black, or blue awn and with white grains in variety coerulescens ; with red grains in variety lybicum and with pubescent red ears with black awn and with red grains in the niloticum variety according to the classification made by Laumont and Erroux, (1961).

The morphology of the ear allowed highlighting several forms in the leucomelan variety, which is the most represented one with 206 genotypes. It can have a white hairless or smooth ear with a fairly low compacity although sometimes more significant, having a flattened triangular shape, sometimes square or rectangular with some blackness over the glumes. The glumellas are extended by black and thick awn, and the grain is generally white, big and elongated. 
Table 1: Proposed Dichotomy Classification of the 1019 accessions of durum wheat

\begin{tabular}{|c|c|c|c|c|}
\hline Hairless white ear & white awn & & $N / G$ & \\
\hline a- White grains & & var. leucurum & 29 & \\
\hline b- Red grains & & var. affine & & 30 \\
\hline Hairless white ear & black awn & & & \\
\hline a- White grains & & var. leucomelan & 206 & \\
\hline b- Red grains & & var. reichenbachi & 176 & \\
\hline Hairless red ear & red awn & & & \\
\hline a- White grain & & var. hordeiforme & 75 & \\
\hline b- Red grain & & var. murciense & 58 & \\
\hline Hairless red ear & black awn & & & \\
\hline a- White grains & & var. alexandrinum & 09 & \\
\hline b- Red grains & & 1- var. erythromelan & 04 & \\
\hline & & 2- var. algeriense & 06 & \\
\hline Hairless black ear & black awn & & & \\
\hline a- White grains & & var. provinciale & 01 & \\
\hline b- Red grains & & var. obscurum & 03 & \\
\hline \multicolumn{5}{|c|}{ Pubescent white ear white awn } \\
\hline a- White grains & & var. valenciae & 50 & \\
\hline \multirow[t]{2}{*}{ b- Red grains } & & 1-var. fastuosum & 06 & \\
\hline & & 2- var. circumflescum & 14 & \\
\hline \multicolumn{5}{|c|}{ Pubescent white ear black awn } \\
\hline a- White grains & & var. melanopus & 11 & \\
\hline b- Red grains & & var. africanum & 03 & \\
\hline \multicolumn{5}{|c|}{ Pubescent red ear red awn } \\
\hline a- White grains & & var. italicum & 141 & \\
\hline b- Red grains & & var. aegytiacum & 42 & \\
\hline Pubescent red ear & black awn & & & \\
\hline a- White grains & & var. apulicum & 02 & \\
\hline
\end{tabular}


Variety reichenbachi, with a population of 176 genotypes, presents a fairly loose narrow and hairless white ear with black awn and red medium grains.

Variety Italicum consists of a population of 141 genotypes with pubescent red ear with low compacity, glumellas lengthened by red awn with medium red grains.

Both erythromelan and algeriense varieties with hairless red narrow triangular ear with rather low compacity and of which glumellas are lengthened and that differ only by the long upright black parallel silks sometimes big for the first and by curved awn at the bottom for the second.

Fastuosum and circumflescum varieties have pubescent red ear with white silks and red grain. However, fastuosum variety has upright parallel awn whereas circumflescum variety has rather curved awn at the bottom.

The classifications were made by many authors on the basis of different criteria as Kornick, (1885); Orlov, (1922); Ducellier, (1930); Bœuf,( 1932); Laumont in Erroux, (1949); Laumont and Erroux, (1961) and Fassil et al., (2001) who were interested in the morphological features of the ear.

Vavilov, (1936-1950) and Grignac, (1965) stuck to the botanic description and the geographical origin.

Spagnoletti and Qualset (1987 and 1990) took only certain morphological characters of the ear and the diversity of the standard leaf.

Asins and Carbonell, (1989) proposed a classification based on isozymes.

Magdalena et al., (1997); Tranquilli et al., (2000) and Penko et al., (2001) took account of the agro /morphological and biochemical characteristics of wheat.

Another classification is presented by Grignac, (1965) who based it partly on the ear color and awn as well as their fluctuations in absence of accident at maturity and partly on the grain color once more considering the geographical criteria.

Bœuf, in 1932, stated the hypothesis that the multiplicity of the forms encountered in North Africa could be due to hybridisations and spontaneous crossbreedings.

Referring to the history of durum wheat in Algeria, Orlov, (1922) reports in these works that Algeria had a very high variability of forms, in which he discerned 22 botanic varieties in the whole 34 he knew.

Botanic classification done by Ducellier, (1930) mentions 29 botanic varieties. As for Laumont and Erroux, (1961), they identified 22 varieties among which there are 19 varieties that we determined from cultivated wheat accessions. It clearly appears that an impoverishment of the varieties occurred in the last decades, as previously reported by Abdelguerfi, (1999).

Our collection consists only of 19 varieties, some of which are very mildly represented.

Morphological Variability : In order to study the morphological variability among 1019 genotypes out of 19 varieties obtained, an overall discriminating factorial analysis (ODFA) was performed on a data matrix in order to materialise the combinations of the variables that discriminate to the best genotypes. The ODFA shows that the 3 first axes express respectively $73.3 \%, 14 \%$ and $8.1 \%$ of the information, that is, a total $95.4 \%$ (tab.2).

Table 2: Main Characteristics of Axes of the DFA.

\begin{tabular}{|c|c|}
\hline Axis & Inertia \\
\hline 1 & $73.3 \%$ \\
\hline 2 & $14.1 \%$ \\
\hline 3 & $8.1 \%$ \\
\hline
\end{tabular}

Study of the Variables: The main variables that seem to play a prominent part in group discrimination are:

The characters of vegetation as glume pilosity(GLP), rachis pilosity (RP), glume color (GLC ), awn length( $A L$ ), awn color (AC), ear form and color ear (EF,CE).

The character of the output which is the ear compacity (COE).

The character of the quality which is the color of the grain (CGR) ( Tab.3). 
Table 3 : Values of Fisher Senedecor

$\begin{array}{cc}\text { Variable } & F(18 / 847) \\ \text { PGL } & 2375.42 \\ \text { CGR } & 2347 \\ \text { CA } & 2321 \\ \text { COE } & 1701 \\ \text { CGL } & 386.86 \\ \text { FE } & 20.57 \\ \text { CE } & 16.40 \\ \text { PR } & 13.61 \\ \text { LA } & 9.69\end{array}$

In plan 1-2, the best represented variables on axis 1 of the positive side are the number of spikelets (NSP ), the ear number ( $E N)$, the pilosity and color of the glume ( $P G L, C G L$ ), the pilosity of the rachis ( $P R$ ), compacity of the ear( COE ), glaucescence of peduncle, sheath and ear(GP,GS, GE), grains/ear weights (WGR/E ), number of grains/ear (NGR/E ) and length of the neck ( LN). These are opposite the form of the grain (FGR), colour and length of the awn ( CA, LA ) located on the negative side of this axis (Tab:4).

This axis discriminates to the best the characters that detail the morphological parameters related to the adaptation to water deficit and yield. The latter can designed as an "axis of adaptation and yield".

As for axis 2, variables being part of its constitution in its positive part are: grain color (CGR) and form of the lower glume beak (FBE) and in its negative part: form of the truncation (FT).

This axis could be considered as an "morphological of the ear axis".

In plan 1-3, axis 3 presents $8 \%$ information. The variables contributing to its formation are : form and length of the ear (FE, LE) in the positive sense and ear color (CE) and the one-thousand-grain weight ( WTGR) in the negative sense.

Discriminate axis 3 can be qualified as the "morphological and yield axis".

Study of the individuals: The graphic representation of genotypes on plan 1-2, showed a formation of spots cloud belonging to different varieties. Varieties aegyptiacum (G16), provinciale (G4), obscurum (G5), valenciae (G6) and italicum (G17) are grouped on the positive side of axis 1 showing some similarity. They differ from the other varieties by the color of the glume, the number of spikelets, the compacity of the ear, the pilosity of the rachis, the weight of the grains/ear and the number of grains lear, the length of ear neck and the glaucescence of the peduncle, sheath and ear. On the negative side of this axis, there are two varieties: leucomelan (G19) and reichenbachi (18) which is characterised by the grain shape and by the length and color of the awn.

Concerning axis 2, varieties fastuosum (G14) and circumflescum (G15) located on the positive side are characterised by the red color of the grains.

grain color is a character controlled by well-known genes R2 and R3 localised in soft wheat on chromosomes 3A and $3 \mathrm{~B}$ (Melntosh and Cusik, 1987).

projection of the varieties on plan 1-3 reveals on the positive side of axis 3 varieties leucurum (G1) and affine (G2) which are distinguished by the form and length of the ear and are opposed to varieties apulicum (G7) melanopus (G8) and africanum (9) by the one-thousand-grain weight and ear color.

Ear neck length was frequently proposed as a selective criterion of genotypes tolerant to water stress(Fisher and Turner, 1979). Therefore, its role is accounted for the quantities of assimilates stored in this part of the plant and likely to be driven to the grain, even in conditions of water stress according to Ali Dib et al, (1990).

Clarke et al. (1988), showed glaucescence mitigated waste of water (cuticle transpiration) in dry conditions and the varieties that have a high glaucescence give outputs that are higher than varieties with mild glaucescence. Besides, glaucescence might delay foliar senescence. Moreover, Richard, (1983); Jordan et al., (1984) and El-hakimi, (1992) consider glaucescence a morphophysiological parameter of adaptation to water stress.

Streyband and Jenkins, (1961), could prove the pilosity of the glume is controlled by three alleles situated on the same locus, but its physiological signification is unknown. For Panin, (1986) there may be a genetic link between genes of gliadine and those that determine pilosity.

According to Melntosh and Cusik, (1987), grain color is a character which is controlled by well-known genes R2 and R3 located in soft wheat on chromosomes $3 \mathrm{~A}$ and $3 \mathrm{~B}$.

The length of the awn may play an important part in filling the grain. Similarly the number of ears can encounter a decrease if the water shortage occurs 
during the elongating phase of the ears (Gate et al., 1992).

The form of the grain depends on the cloaks that are influenced by the climatic conditions during the period of their formation (Masse, 1987) and the filling of the grain which can be limited in relation to the genotype and the medium (Blade and Backer, 1991).

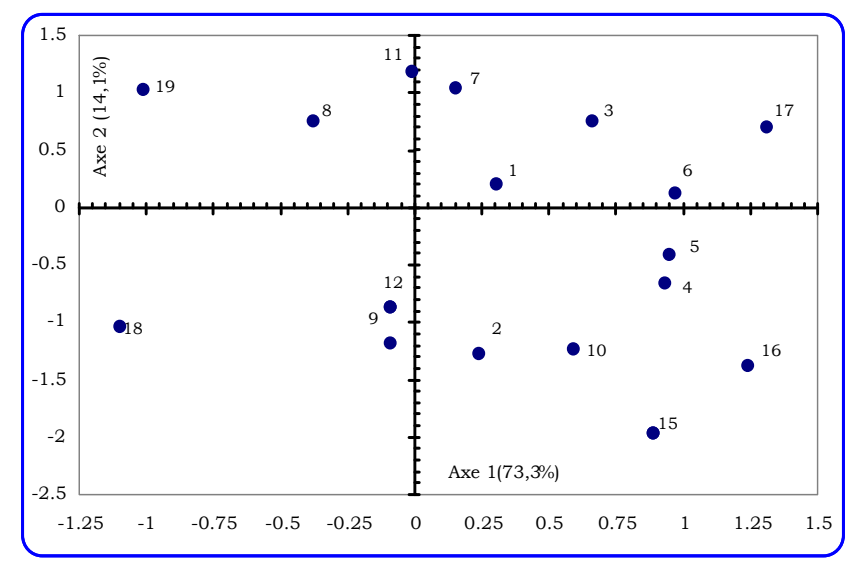

Fig-1-Positions of the gravity centres of the different botanic varieties

\section{Groups witnessed Groups hidden}

The interpretation and qualification of the axes lead us to consider the two varieties leucomelan and reichenbachi are the least adapted to water shortage, unlike varieties leucurum, circumflescum, hordeiforme, murciense, italicum, valenciae, obscurum, provenciale, aegyptiacum and fastuosum ,which seem more adapted thanks to their high glaucescence and pilosity. The rest of the varieties have a intermediate behaviour.

Analysis of Distances (D2) of Mahalanobis (annex 2 ), allowed us confirming the level of resemblance between varieties.

In plan 1-2, varieties murciense (G10) and aegytiacum (16) are at a distance of 2.99 from each other.

In plan 1-3, varieties reichenbachi (G18) and leucomelan (G19) are the nearest with a distance of 2.20, as for varieties hordeiforme (G3) and murciense (G10) with a distance equivalent to 2.31. Variety aegyptiacum (G16) is also close to variety italicum (G17) with a distance of 2.42. Varieties leucurum (G1) and affine (G2) are distant by 2.70 .

It is worth to note that varieties provinciales (G4) and fastuosum (G14) are the farthest with a distance 9.14 , because they are actually very different.
Indeed, the first has a black hairless ear with black awn and white grains whereas the second has a white pubescent ear with white awn and red grains (table1).

Classification of genotypes The discrimination procedure revealed a percentage of genotypes

"Well- placed" of $94.6 \%$ and allowed sorting the " illplaced" genotypes in groups different from their original groups. According to the table of grouping (annexe3), it appears that 46 genotypes were reassigned to other groups. We can mention the case of the reichenbachi (18) variety which left most genotypes (10) (annexe 3).

As for the relative " ill-placement" of these genotypes (annex 4), some were reassigned to other groups, but that remained linked to their initial group because they resemble them more. However they get closer to the reassignment groups mainly by certain variables related to axes 1, 2 and 3 as for example the color of the awn and the grain, ear compacity, etc.

Through the results obtained in our study, it appears that the genetic resources of wheat remain highly varied not only by the number of varieties or bred populations but also and especially by the very large genetic diversity in each population.

\section{REFERENCE}

Abdelguerfi, A. and Laouar, M. 1999. Les ressources génétiques en Algérie: un préalable à la sécurité alimentaire et au développement durable. INESG (Alger); 1-108.741.

Ali .Dib., Monneveux P., and Araus J. L., 1990. Breeding durum wheat for drought Tolerance. Analytical, Synthetical approaches, and their connections symposium. In : « Wheat Breeding- Prospects and Future Approaches », PANAYOTOV I, and PAVLOVA S. (eds), Albena, Bulgaria : 224-240.

Anu. A. and K. V. Peter. 2003. Analysis of seed protein of 29 lines of 'Capsicum annuum L.' by polyacrylamide gel electrophoresis. Genetic Resources and Crop Evolution 50: 239-243.

-Anonyme, 2001. Institut des Grandes Cultures (ITGC) Constantine.

Asfis (catalogue)., 1990. Identification des variétés de blé dur. 69p.

Asins M.J. Carabonell E.A., 1989. Distribution of genetic variability in durum wheat word collection. Theor. Appl. Genet., 77: 287-294. 
Blade SF., Baker RJ., 1991. Kernel weight response to source sink changes in spring wheat. Crop Sci. 31, 1117- 11120.

Bœuf F. 1932. Le blé en Tunisie, Ann. Ser. Botanique et Agronomie. Tunisie. Tunis. 1- 454.

Cardoso- ET; Nedel- JL. , 2002. Electrophoretic patterns of wheat cultivars in Southern Brazil. Ciencia-Rural. 32: 2, 203-209.

Cauderon A., 1986. Ressources génétiques et botaniques. Bull. Soc. Bot. Fr., 133, 7-13.

Clarke J.M., Richard R.A,. 1988. The effects of glaucousness, epicuticular wax, leaf age, plant weigt, and grown environnement on water loss rates of exicesed wheat leaves. Can. J. Plant Sci., 68 : 975982.

Ducellier L., 1930. Espèces et variétés de céréales cultivées en Algérie. In : les céréales d'Algérie. Alger.

Echelle de Feckes,. 1954. Classement Rev2. Agr 1. (1984).

El-Hakimi.A, 1992. Evaluation de la variabilité génétique des caractères d'adaptation liés à la sécheresse chez les espèces tetraploïdes sauvages et cultivés du blé. Thèse pour l'obtention du diplôme de l'école pratique des hautes études.

Erroux, J. 1949. Classification des blés durs cultivés en Algérie. Essai d'établissement d'une clé dichotonique.

Feldman M. et Sears E., 1981. Les ressources génétiques naturelles du blé. Science, No 41, 79-89.

Fassil Kebebew, Yemane Tsehaye and Tom McNeilly., 2001. Morphological and farmers cognitive diversity of barley ( Hordeum vulgare L. 'Poaceae' ) at bale and North Shewa of Ethiopa. Genetic Resources and Crop Evolution, 48 :467-481.

Fisher R.A., Turner N.C., 1978. Plant productivity in arid and semi arid zones. Ann. Rev. Plant Physiol. 29: 277-317.

Gate P., Bouttier A. and Moynier J.L., 1992. La tolérance des variétés à la sécheresse : une réalité à valoriser Perspectives Agricoles no 169, 62-67

Grignac p., 1965. Contribution à l'étude du triticum durum. Thèse de Doctorat, université de Toulouse.pp.246.

Jordon W.R., Shouse P.J., Miller F.R et Monk R.L., 1984. Environnemental physiology of sorghum.II. Epiticular wax and load and cuticular transpiration. Crop Sci., $24,1168-1173$.

Kolev-K., 2001. The national collection of common wheat -initial material for the breeding work. Rasteniev"dniNauki. 38: 2, 73-76.
Kornicke F., Werner II., 1885. Hand- buch des Getreidebaues.2 vol., P. Parey, Berlin.

Laumont, P.; Erroux, J. 1961. Inventaires des blés durs rencontrés et cultivés en Algérie. 95p.

Magdalena Ruiz, Federico Varela and Jose M. Carrilo., 1997. Analysis of the discriminating power of agro/morphological and biochimical descriptors in a semple of the Spanish collection of barley ( Hordeum vulgare L. ) Genetic Resources and Crop Evolution 44: 247-255.

Majoul-T; Bancel-E; Triboi-E; Hamida-JB; Branlard-G., 2003. Proteomic analysis of the effect of heat stress on hexaploid wheat grain: characterization of heatresponsive proteins from total endosperm. Proteomics. 3: $2,175-183$.

Masse J., 1987. La maturation du blé dépend surtout du climat. Bull. Frams semences n0 100, été 1987.

Mclntosh R.A.,Cusik J.E., 1987. Linkage mape of hexaploid wheat; In wheat and wheat improvement, 2è me édition E.G. Heyne, Madison, 289-322.

Nia-FS; Rezai-AM., 2002. An evaluation of quantitative and qualitative characteristics of breeding lines, cultivars and landrace varieties of bread wheat using multivariate statistical analysis. Iranian-Journal-ofAgricultural-Sciences. 33: 1, 89-102.

Orlov, 1922. The géographical centre of origin and the area of cultivation of durum wheat. Bull of Applied Bot. Genetics and Pl. Breeding, X111 the, Vol.1. Petrograd.

Panin V.M., 1986. Linkage of gliadin coding loci with genes for hairness and red coloration of the glumes in winter durum wheat. Sel. Semenovod. Agrotekh. Zernovskyl Kul't, 51-57.

Payne, P.I.; Corfield, K.G.; J.A. Blackman., 1979. Identification of high molecular

Weight subunit of glutenin whose presence correlates with bread-makeing quality in wheats of related pedigree. Theory. Appl. Genet., 55, 153-159.

Penko Atanassov; Christiane Borries; Maria Zaharieva and Phillipe Monneveux., 2001. Hordein polymorphism and variation of agromorphological traits in a collection of naked barley. Genetic Resources and Crop Evaluation 48 : 353-360.

Richard R.A., 1983. Glaucousness in wheat, its effect on yield and related characteristics in dryland environnemnts and its control by minor genes. Proc. 6 th. International wheat genetics, pp 447-451.

Ruiz. J.I de galarreta and A. Alvarez., 2001. Morphological classification of maize landraces from narthen Spain. Genetic Resouces and Crop Evolution 48: 391-400. 
Spagnoletti- Zeuli P.L.,Qualset C.O., 1987. Geographical diversity for quantitative spike characters in a word collection of durum wheat. Crop. Sci., 27 : 235-241.

Spagnoletti- Zeuli P.L., Qualset C.O., 1990. Flag leaf variation and the analysis of diversity in durum wheat. Plant Breeding, 102-5: 189-202.

Streyband H.A. and Jenkins B.C., 1961. The inheritance of glume pubescence in some durum variétés. Can. J. Genet. Cyto. 3, 23-25.

Szwed Urbas K; SwiecickiW (ed.); NaganowskaB (ed.) WolkoB. 2002. Differentiation of biometric features in the Triticum durum Desf. Collection. Broad-variationand -precise-characterization-limitation-for-the-future.Proceedings-of-the-XVIth-EUCARPIA-GeneticResources-Section-workshop,-Poznan,-Poland,-16-20-May-, 276-280.

Tranquilli G., M. L. Appendino, L. A. Pflûger, L. Bullrich, S. Lewis et E. Y. Suarez., 2000. Morphoagronomic and biochemical variation in an Argentinean landrace of wheat. Genetic Resources and Crop Evolution 47: 281-284.

Triboi-E; Triboi-Blondel-AM; Gooding-MJ (ed.); Barton-SA (ed); Smith-GP., 2001. Environmental effects on wheat grain growth and composition. Aspects-of-AppliedBiology. No. 64, 91-101.

Triboi-E ; $\quad$ Martre-P ; Triboi-Blondel-AM., 2003. Environmentallly-induced changes in protein composition in developing grains of wheat are related to chages in total protein content. Journal-ofexperimental-Botany. 54: 1731-1742.

UPOV. 1979. Introduction générale révisée aux principes directeurs pour la conduite de l'examen des caractères distinctifs, de l'homogénéité et de stabilité des obtentions végétales. TG1/1- TG1/2.

UPOV., 1990, 1991. Convention internationale pour la protection des obtentions végétales, Genève 1991.

Vavilov N.I., 1936. Studies on the origin of cultivated plants. Bull. App. Botany and plant breeding, 16, 1248.

Vavilov N.I., 1950. The origin, variation, imunity and heridity of cultivated Chronica Botanica 13, 1-364.

Wan-Y; Wang-D; Shewry-PR; Halford-NG., 2002. Isolation and characterization of five novel high molecular weight subunit of glutenin genes from Triticum timopheevi and Aegilops cylindrica. Theoretical-andApplied-Genetics.104: 5,828-839.

Worniak- A. 2001. Content and yield of total protein in grain of spring triticale, spring wheat and spring barley in crop rotations and monoculture.

Biuletyn-Instytutu-Hodowli-i-Aklimatyzacji-Roslin. No.217, 87-93 